\title{
Does Nrf2 help nerves to survive?
}

\section{OPEN}

Klemens Ruprecht, MD

Friedemann Paul, MD

Correspondence to Dr. Paul:

friedemann.paul@charite.de

Neurol Neuroimmunol

Neuroinflammation

2015;2:e105; doi: 10.1212/ NXI.0000000000000105
Dimethyl fumarate (DMF) has recently been approved for the treatment of relapsing-remitting multiple sclerosis (RRMS) after showing beneficial effects on clinical and radiologic endpoints in 2 phase 3 clinical trials. ${ }^{1,2}$ While DMF's mode of action is not completely understood, experimental data suggest that putative neuroprotective properties may be mediated by the nuclear factor (erythroid-derived 2)-like 2 (Nrf2) pathway. ${ }^{3,4}$ Specifically, DMF leads to translocation of $\mathrm{Nrf} 2$ to the nucleus, thereby enhancing the expression of antioxidant enzymes and promoting neuroprotection in cell culture models. ${ }^{4}$ In line with this, DMF improved the clinical course and preservation of myelin, axons, and neurons in an animal model of MS. These effects were lost in Nrf2-deficient mice, suggesting a central role for Nrf2 in mediating neuroprotection. ${ }^{3}$

In this issue of Neurology ${ }^{\circledR}$ Neuroimmunology \& Neuroinflammation, Metz et al. ${ }^{5}$ report on a patient with RRMS who after more than 1 year of DMF treatment underwent brain biopsy for a large unusual left occipital lesion. Histopathologic workup of this lesion revealed a more than 6-fold higher number of Nrf2-positive nuclei than control lesions from patients with MS not treated with DMF. The most prominent nuclear Nrf2 signal was observed in astrocytes, whereas other cell types such as oligodendrocytes and lymphocytes displayed a predominantly cytoplasmic staining. Metz et al. could also analyze biopsied lesions from 3 patients with psoriasis who had developed progressive multifocal leukoencephalopathy (PML) as a rare complication of ongoing fumarate treatment. Lesions from 2 of those $3 \mathrm{pa}-$ tients likewise exhibited higher numbers of Nrf2positive nuclei than control PML lesions.

Although based on only a few cases, these data provide circumstantial evidence that DMF treatment may induce nuclear translocation of Nrf2 in CNS cells in vivo, thus potentially preventing oxidative damage of neurons and glial cells in vivo.
Nevertheless, the findings of Metz et al. are derived from single biopsies and therefore do not permit us to draw conclusions on the temporal dynamics of Nrf2 expression. Another note of caution is that the MS lesion was biopsied 8 weeks after the last DMF dosage, raising the question as to whether levels of DMF would have been sufficiently high to exert biological functions at that time. Although the results of Metz et al. therefore do not formally prove Nrf2 nuclear translocation in patients treated with fumarate, they are consistent with previous observations in cell culture experiments and allow for the possibility that a similar mechanism may operate in vivo.

Do these intriguing findings indicate that $\mathrm{Nrf2}$ helps nerves to survive? Findings from the experimental autoimmune encephalomyelitis model indeed suggest that DMF treatment may be associated with an ameliorated disease course, in particular in the late stages of the disease. ${ }^{3}$ However, answering the question of whether DMF's interesting effects in cell culture and animal models translate into measurable and clinically meaningful neuroprotective effects in patients will require carefully designed long-term studies with appropriate endpoints. In this regard, 2 recent phase 3 trials of DMF for RRMS have evaluated the effects of DMF treatment on the reduction of brain atrophy, an MRI surrogate measure of neuroprotection. ${ }^{6,7}$ In the DEFINE study, relative reductions in brain atrophy over a 2-year period were statistically significant only for DMF twice daily but not 3 times daily. ${ }^{6}$ In the CONFIRM study, reductions in brain atrophy with DMF compared with placebo did not reach statistical significance over a 2-year period.7 Thus, these studies do not yet seem to provide definitive evidence for neuroprotective effects of DMF, at least as measured by the reduction of brain atrophy on MRI. MRI studies with a longer follow-up appear to be warranted to further analyze those effects. Finally, and perhaps most importantly,

From the Department of Neurology (K.R., F.P.), Clinical and Experimental Multiple Sclerosis Research Center (K.R., F.P.), and NeuroCure Clinical Research Center (F.P.) Charité-Universitätsmedizin Berlin, Germany.

Funding information and disclosures are provided at the end of the editorial. Go to Neurology.org/nn for full disclosure forms. The Article Processing Charge for this editorial was waived at the discretion of the Editor.

This is an open access article distributed under the terms of the Creative Commons Attribution-Noncommercial No Derivative 4.0 License, which permits downloading and sharing the work provided it is properly cited. The work cannot be changed in any way or used commercially. 
the ultimate measure of neuroprotective properties of any disease-modifying therapy for MS will be the demonstration of beneficial effects on the patients' overall level of functioning, including cognitive and motor capacities, in the long term.

\section{NOTE ADDED IN TEXT}

DMF's safety profile is generally considered favorable; however, a recent case of PML underscores the necessity for further pharmacovigilance. ${ }^{8}$

\section{STUDY FUNDING}

No targeted funding reported.

\section{DISCLOSURE}

K. Ruprecht has received research support from the German Ministry of Education and Research (BMBF/KKNMS, Competence Network Multiple Sclerosis) and Novartis; has received speaking fees and/or travel grants from Bayer Healthcare, Biogen Idec, Merck Serono, sanofi-aventis/ Genzyme, Teva Pharmaceuticals, Novartis, and Guthy-Jackson Charitable Foundation; is an academic editor for PLOS ONE; and received publishing royalties from Elsevier. F. Paul has received research support from Deutsche Forschungsgemeinschaft, the German Ministry of Education and Research (BMBF/KKNMS, Competence Network Multiple Sclerosis), BMWi, Guthy-Jackson Charitable Foundation, and Arthur Arnstein Foundation; has received speaker honoraria and travel reimbursement from Biogen Idec, Bayer, Teva, Merck Serono, Novartis, and Genzyme; is an academic editor for PLoS ONE; has consulted for Sanofi/Genzyme, Biogen Idec, and MedImmune; and is on the study steering committee for Novartis OCTIMS. Go to Neurology.org/nn for full disclosure forms.

\section{REFERENCES}

1. Fox RJ, Miller DH, Phillips JT, et al. Placebo-controlled phase 3 study of oral BG-12 or glatiramer in multiple sclerosis. N Engl J Med 2012;367:1087-1097.

2. Gold R, Kappos L, Arnold DL, et al. Placebo-controlled phase 3 study of oral BG-12 for relapsing multiple sclerosis. N Engl J Med 2012;367:1098-1107.

3. Linker RA, Lee DH, Ryan S, et al. Fumaric acid esters exert neuroprotective effects in neuroinflammation via activation of the Nrf2 antioxidant pathway. Brain 2011;134:678-692.

4. Scannevin RH, Chollate S, Jung MY, et al. Fumarates promote cytoprotection of central nervous system cells against oxidative stress via the nuclear factor (erythroid-derived 2)like 2 pathway. J Pharmacol Exp Ther 2012;341:274-284.

5. Metz I, Traffehn S, Straßburger-Krogias K, et al. Glial cells express nuclear Nrf2 after fumarate treatment for multiple sclerosis and psoriasis. Neurol Neuroimmunol Neuroinflamm 2015;2:e99. doi: 10.1212/NXI.0000000000000099.

6. Arnold DL, Gold R, Kappos L, et al. Effects of delayedrelease dimethyl fumarate on MRI measures in the Phase 3 DEFINE study. J Neurol 2014;261:1794-1802.

7. Miller DH, Fox RJ, Phillips JT, et al; CONFIRM study investigators. Effects of delayed-release dimethyl fumarate on MRI measures in the phase 3 CONFIRM study. Neurology 2015;84:1145-1152.

8. Rosenkranz T, Novas M, Terborg C. PML in a patient with lymphocytopenia treated with dimethyl fumarate. N Engl J Med 2015;372:1476-1478. 


\section{Neurology $^{\odot}$ \\ Neuroimmunology \& Neuroinflammation}

Does Nrf2 help nerves to survive?

Klemens Ruprecht and Friedemann Paul

Neurol Neuroimmunol Neuroinflamm 2015;2;

DOI 10.1212/NXI.0000000000000105

This information is current as of May 14, 2015

\section{Updated Information \& Services}

References

Subspecialty Collections

Permissions \& Licensing

Reprints including high resolution figures, can be found at:

http://nn.neurology.org/content/2/3/e105.full.html

This article cites 8 articles, 1 of which you can access for free at: http://nn.neurology.org/content/2/3/e105.full.html\#\#ref-list-1

This article, along with others on similar topics, appears in the following collection(s):

All Immunology

http://nn.neurology.org//cgi/collection/all_immunology

Autoimmune diseases

http://nn.neurology.org//cgi/collection/autoimmune_diseases

Multiple sclerosis

http://nn.neurology.org//cgi/collection/multiple_sclerosis

Information about reproducing this article in parts (figures,tables) or in its entirety can be found online at:

http://nn.neurology.org/misc/about.xhtml\#permissions

Information about ordering reprints can be found online:

http://nn.neurology.org/misc/addir.xhtml\#reprintsus

Neurol Neuroimmunol Neuroinflamm is an official journal of the American Academy of Neurology.

Published since April 2014, it is an open-access, online-only, continuous publication journal. Copyright $(0$ 2015 American Academy of Neurology. All rights reserved. Online ISSN: 2332-7812.

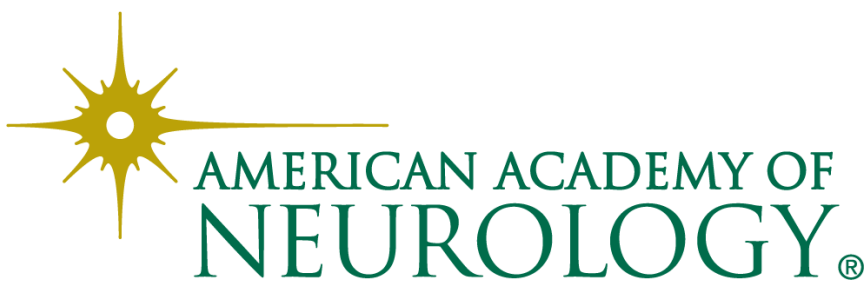

